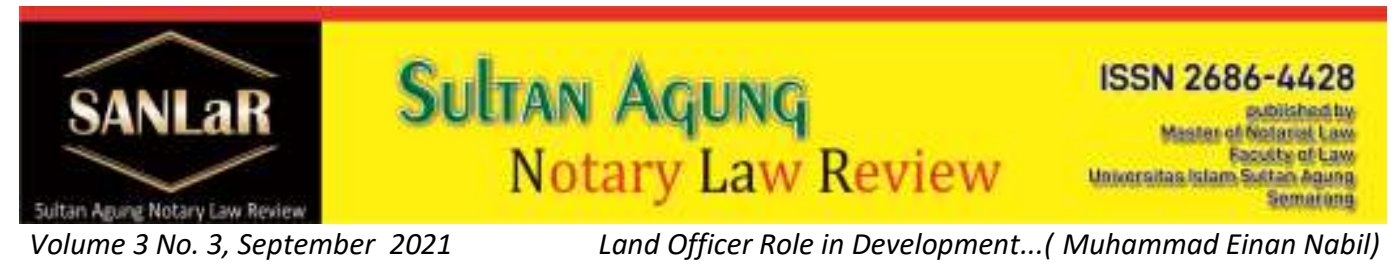

\title{
Land Officer Role in Development of Sharing Collective Rights to Heirs with Mental Disability
}

\author{
Muhammad Einan Nabil*) \\ ${ }^{*}$ Faculty of Law, Universitas Islam Sultan Agung (UNISSULA) Semarang, E-mail: \\ nabilen@gmail.com
}

\begin{abstract}
Land Deed Making Official/PPAT is an official who is given the authority to make an authentic deed that can be trusted. The division of inheritance for the heirs can be the right of each of the holders of the joint rights based on the Deed of Sharing the Joint Rights made by the PPAT. The purpose of this research is to find out the role of PPAT in making $A P H B$ and what to do if one of the heirs is incompetent the process after $A P H B$ is made along with examples from APHB. This study uses a normative juridical approach, The data analysis method used is a qualitative analysis method with descriptive analytical research specifications, data collection methods with literature study, data sources used are secondary data. Based on the results of research and discussion: 1) PPAT has an important role, namely the General Official who helps the parties to achieve their wishes, prepares and registers a transfer of rights to share rights with a land right at the Land Office, and has the authority to make APHB as an authentic deed; 2) When an heir is incompetent due to a mental disability, the heir is represented by the custodian because people with mental disabilities are usually not able to carry out activities like people in general; 3)PPAT is obliged to register the transfer of rights to the local Land Office after the APHB is made; 4) Sample APBH made by PPAT. It is recommended that PPAT must master the law of inheritance in carrying out their duties. A custodian must be responsible for all legal actions committed by the holder. The government, especially the National Land Agency, is expected to further socialize all regulations regarding land, especially regarding Land Registration.
\end{abstract}

Keywords: Role; Deed; Sharing; Rights; Incompetent; Inheritance.

\section{Introduction}

Civil law is a set of legal provisions that regulate the interests of individuals in their efforts to meet their needs and for society. This Civil Law is said to be private law, because what is regulated is about the relationship and interests of one individual/individual with another individual. ${ }^{1}$ Notary/PPAT is one of the institutions mentioned in the Civil Code whose authority is closely related to the making of authentic deeds and other authorities.

${ }^{1}$ Yosvita Prasetyaningtyas, Hukum untuk Orang Awam, (Yogyakarta: Efata Publising, 2014), p. 21. 
In social life it cannot be separated from the relationship with one another, what is most often done by a person or legal entity to maintain/bind the relationship is through an agreement or contract. Given the importance of an agreement, so that problems do not arise in the future due to someone's lack of understanding in making an agreement, there are several conditions that must be met in order for the agreement to be valid and binding on the parties. Article 1320 of the Civil Code states that there are 4 (four) conditions for the validity of an agreement, namely:
a. There is an agreement for those who bind themselves;
b. The ability of the parties to enter into an engagement;
c. A certain thing; and
d. A lawful cause.

The first and second requirements are called subjective terms because they relate to the subject of the agreement. Meanwhile, the third and fourth requirements regarding the object of the agreement are called objective conditions ${ }^{2}$.

An ownership of land rights is caused by a transfer of rights that can occur due to legal actions and/or legal events. The transfer of land rights due to legal actions is an action desired by the parties, giving rise to rights and obligations such as buying and selling, exchanging, grants, will grants. While the transfer of land rights that occurs due to legal events is an event that occurs due to the death of a person so that the property left behind is transferred to the heirs. In a family, it is certain that there will be an inheritance process or also often referred to as inheritance. The purpose of inheritance of land rights is so that the heirs can legally control and use the land.

The process of inheritance in the form of land often occurs in people's lives, given the high economic value of the land. This often triggers disputes in society, even within the family. Not a few family members (heirs) are involved in disputes over inheritance. ${ }^{3}$ The transfer of inheritance to the heirs will lead to joint ownership of the property. Individual control is one of the wishes of the heirs to control a land right. Ownership of individual land rights if the number of heirs is more than two or more people is called joint ownership of an object, this requires a different right base. The underlying principle is the Deed of Sharing Joint Rights (APHB) made by the Land Deed Making Official (PPAT).

\footnotetext{
${ }^{2}$ Deen, Thaufiq., Ong Argo Victoria \& Sumain. (2018). Public Notary Services In Malaysia. JURNAL AKTA: Vol. 5, No. 4, 1017-1026. Retrieved from http://jurnal.unissula.ac.id/index.php/akta/article/view/4135

${ }^{3}$ Tatik Arjiati, Peran Notaris/PPAT dalam Pembuatan Akta Pembagian Hak Bersama (APHB) terhadap Pembagian Waris yang Berbeda Agama atas Tanah dan Bangunan, Jurnal Akta Vol. 4. No. 1,(Semarang: Universitas Islam Sultan Agung, 2017), p. 75
} 
APHB is a deed made by PPAT to be able to prove the agreement between the joint rights holders regarding the distribution of the joint rights to a land right so that it becomes the right of one or several of the joint rights holders.

Basically, experts inheritance is a legal subject who has legal authority, however, not all legal subjects have the ability or ability to carry out a legal act with perfect legal consequences. There are people who are categorized as incapable of carrying out legal actions, namely because they are not yet mature or in a state that is unable to carry out legal actions on their own with legal consequences for which cancellation may be requested. According to the provisions of the applicable law, such people must be placed under guardianship or guardianship.

Forgiveness is a condition in which a person (called "Curandus") because of his personal characteristics is considered incompetent or not in all respects capable of acting alone in legal traffic. On that basis, the person by a judge's decision is then included in the group of people who are not capable of acting.

\section{Research Methods}

In this study the author uses a library research approach that is juridical normative as a normative science (law science) has its own characteristics or methods that are social sciences, how are the legal problems faced by the community, especially regarding inheritance regulation through legislation and the method of transferring rights to inherited land from in the practice that occurs in society. Normative legal research is also known as doctrinal legal research or library research.

To analyze the legal material that has been collected, this study uses a qualitative data analysis method, namely normative juridical which is presented in an analytical descriptive manner, which describes the applicable laws and regulations associated with legal theories and their implementation practices. In the preparation of this thesis the data used are Secondary Data. Secondary data is a source of research data obtained through intermediary media or indirectly in the form of books, records, existing evidence, or archives, both published and unpublished in general. Secondary data is classified into:

1) Primary Legal Material

Primary legal material is the main legal material. Primary legal materials include statutory regulations and all official documents containing legal provisions. Ingredients primary laws in this thesis are:

- Constitution of 1945 the Republic of Indonesia

- Act No. 5 of 1960 concerning Basic Regulations on Agrarian Principles

- Act No. 1 of 1974 concerning Marriage

- Act No. 3 of 2006 concerning Amendments to Act No. 7 of 1989 concerning Religious Courts. 
- Government Regulation Number 24 of 1997 concerning Land Registration.

- Government Regulation Number 37 of 1998 concerning the Position Regulation of Land Deed Maker Officials.

- Regulation of the Minister of State for Agrarian Affairs/Head of the National Land Agency Number 3 of 1997 concerning Provisions for the Implementation of Government Regulation Number 24 of 1997 concerning Land Registration.

- Regulation of the Head of the National Land Agency Number 1 of 2006 concerning Provisions for the Implementation of Government Regulation Number 37 of 1998 concerning the Regulation of the Position of the Official for Making Land Deeds.

- Regulation of the Head of the National Land Agency Number 8 of 2012 concerning Amendments to Regulation of the Minister of State for Agrarian Affairs/Head of BPN RI Number 3 of 1997 concerning Provisions for the Implementation of Government Regulation Number 24 of 1997 concerning Land Registration.

- Circular Letter of the Supreme Court Number 3 of 1963 concerning the idea of not considering Burgerlijk Wetboek as a law.

- Code of Civil law.

2) Secondary Legal Material

Secondary legal materials from this research are in the form of legal opinions / doctrines / theories obtained from legal literature, research results, scientific articles, and websites related to research. Secondary legal materials are used to provide explanations for primary legal materials. With secondary legal materials, researchers will be helped to understand/analyze primary legal materials. ${ }^{4}$

3) Tertiary Legal Material

Tertiary legal materials are legal materials that provide explanations and instructions for primary legal materials and secondary legal materials. Usually tertiary legal materials are obtained from the Legal Dictionary, the Big Indonesian Dictionary (KBBI), the English Dictionary, and so on.

\section{Result and Discussion}

3.1. The Role of PPAT in Making the Deed of Sharing Joint Rights

Based on the Government Regulation of the Republic of Indonesia Number 24 of 2016 concerning Amendments to Government Regulation Number 37 of 1998 concerning the Position Regulation of Land Deed Maker Officials, Land Deed Making Officials (PPAT) are public officials who are authorized to make authentic deeds regarding certain legal actions regarding Land Rights or Ownership Rights to Flat Units. The deed made by the PPAT is evidence that a certain legal act has been carried out regarding land rights or property rights over flat units. PPAT has

${ }^{4}$ https://ngobrolinhukum.wordpress.com/2014/08/09/data-sekunder-dalam-penelitian-hukumnormatif/, accessed on Thursday, 31 December 2020, at 00.31 WIB 
a work area in one working area of the Regency/City Land Office. PPAT in making the Deed of Sharing Joint Rights (APHB) has an important role, namely:

a. Public Officials tasked with assisting the wishes of the parties to achieve their wishes

If at any time there are parties who come before the process of sharing joint rights in the form of inherited land, then the PPAT is obliged to provide various directions ranging from requirements, procedures, procedures, taxation, to the legal consequences of carrying out the legal act. However, in carrying out his duties as legal advisor to the Land Deed Making Officer, it is only limited to providing direction, but everything is still based on the decisions of the parties with notes in accordance with the provisions of the applicable laws and regulations. The purpose of the process of sharing joint rights in the form of land and buildings in inheritance is so that the heirs get a share according to their respective rights according to mutual agreement. ${ }^{5}$

b. Prepare Requirements Documents Before the Transfer of Shared Rights is Registered at the Land Office

PPAT has the main task of carrying out land registration activities by making a deed as evidence that certain legal actions have been carried out regarding land rights or property rights to flat units, which will then become the basis for registering changes in land registration data as a result of the legal action. ${ }^{6}$ The role of PPAT begins with the provisions of Government Regulation Number 24 of 1997 concerning Land Registration Article 6 Paragraph (2) explains that in carrying out land registration, the Head of the Land Office is assisted by PPAT and other officials assigned to carry out certain activities according to the relevant laws and regulations. .

The purpose of this land registration is to provide legal certainty and legal protection to the holder of the right to a registered plot of land in order to prove that he is the holder of the right to a parcel of land and to provide information on interested parties including the government so that they can easily obtain information data needed in carrying out legal actions regarding registered land parcels, for the orderly implementation of land administration. ${ }^{7}$

PPAT is obliged to examine the formal and material requirements regarding the subject and object of rights, which include:

${ }^{5}$ Laura Chrismetin, Peran Pejabat Pembuat Akta Tanah (PPAT) Dalam Pembuatan Akta Pembagian Hak Bersama (APHB) Terhadap Pembagian Waris Dalam Hukum Islam Atas Tanah Dan Bangunan Di Kabupaten Brebes, (Tegal: Universitas Pancasakti, 2019), p. 51

${ }^{6}$ Article 2 Government Regulation Number 37 of 1998 concerning Regulation of the Position of Land Deed Maker Official

${ }^{7}$ Laura Chrismetin, Op.cit., p. 63 
- The validity of the Certificate of Inheritance;

- Joint Rights Sharing Deed (APHB);

- Identity of the heirs (Identity Card, Family Card, Marriage Certificate);

- Death Certificate;

- 2 (two) witnesses in the Certificate of Inheritance;

- Taxation (Tax Notice Payable Land and Building Tax), and other supporting letters.

- PPAT has the authority to make an authentic deed in the form of a deed of sharing of joint rights

An authentic deed is the strongest and most complete evidence that has an important role in every legal relationship that exists in society, one of which is the Deed of Sharing Joint Rights (APHB). The main role of a Land Deed Making Official in the process of distributing joint rights in the form of land and buildings is to make a Deed of Sharing Joint Rights (APHB). This is based on the provisions in Article 5 of Government Regulation Number 24 concerning Land Registration, which states that the distribution of joint rights to the rights of each joint right holder is registered based on a deed made by the authorized PPAT according to the applicable regulations that prove the agreement between the rights holders together regarding the distribution of these joint rights.

The APHB made by PPAT is evidence of an agreement between the holders of joint rights regarding the distribution of joint rights to land which is the basis for land registration.

Land registration has the aim of providing legal protection to the holder of the right to a plot of land and other rights registered in the land book so that he can easily prove himself as the holder of the right in question. Therefore, PPAT must understand and master the legal aspects that will be used as the basis or basis for rights and supporting data in every authentic deed making.

The authentic deed is the only basis for the transfer of land rights which the author considers the safest, where in the process of making the PPAT it guarantees the certainty of the signer, the certainty of the parties, the certainty of the time of signature, and the certainty of the contents of the deed, and the parties will not be able to deny for what they have made in relation to the deed, therefore legal certainty and protection to the parties will be guaranteed.

\subsection{Sharing of Joint Rights When One of the Heirs is Incompetent}

An heir is mentally handicapped, the heir is represented by his guardian (curator). Mental disability (mental retardation / mental retardation) is a condition when a person's intelligence or mental ability is below average, 
accompanied by a lack of skills in carrying out daily activities. ${ }^{8}$ A person with a mental disability is usually not able to carry out activities like other people in general, he needs the help of others to take care of all his needs to stay alive. Therefore, in the distribution of inheritance, heirs who have mental disabilities will be sidelined because they are considered not to know or are unable to take care of themselves, let alone take care of their inheritance. Mentally disabled heirs cannot perform a legal action in any form, whether it is an agreement, agreement, or other things that can cause legal consequences in it.

Heirs with mental disabilities still have the right to inherit, but to use the inheritance he must be placed under guardianship, namely the person being empowered is assisted by an authorized guardian. Basically, a person who is placed under guardianship does not have the ability to act alone in carrying out legal actions or actions, for that they must be represented by the guardian. It can be interpreted that the right to inherit belongs to the custodian but the implementation is assisted by the custodian. The legal consequence of a person who is placed under custody is that he is equated with a child or a person who is not old enough. So that all legal actions carried out by people who are under guardianship, without being assisted by the guardian are null and void. ${ }^{9}$

All requests for pardon must be submitted to the District Court where the person for whom pardon resides. The pardon takes effect from the moment the decision or stipulation is pronounced by the judge. It is possible that the incumbent is not as proposed, this can happen because of the judge's consideration if the incumbent is deemed unqualified so that the judge can appoint another person.

The procedure for a person's request to place another person who is an adult, who is always in a state of extravagance, stupidity, mental disability (crazy) or dark eyes to be put under custody, namely: ${ }^{10}$

- There must be a submission of an application for pardon to the District Court, so that the court cannot put a person under custody without a request from a person who wishes to become a guardian or a person who wishes to be placed under custody (Article 436 of the Civil Code).

- Examination of qualified candidates is carried out. The examination of a qualified candidate will not take place before the person who is requested to be empowered is notified of the contents of the request letter and a report containing the opinions of blood family members. The

\footnotetext{
${ }^{8}$ https://hellosehat.com/mental/mental-lainnya/keterbelakangan-mental/ accessed on Sunday, July 4, 2021, at 11.14 WIB

${ }^{9}$ Article 466 of the Civil Code

10 https://www.kennywiston.com/sekilas-tentang-hukum-pengampuan/ accessed on Wednesday, July 7, 2021, at 20.37 WIB
} 
examination must also be accompanied by other documents of evidence, such as Identity Cards, Family Cards, Marriage Certificates (if the person being mentored is married), and most importantly a letter from the hospital, stating that the qualified candidate is indeed incompetent to perform legal actions.

- If the District Court is of the opinion that these events are important enough to be the basis for a pardon, then it is necessary to hear from the relatives of the same blood or family. This is the most important thing in examining qualified candidates so as not to cause cases in the future (Article 438 of the Civil Code).

- The examination of a qualified candidate is carried out if the qualified candidate can still be summoned or stated about his condition, such as a person who is placed under guardianship due to extravagance. However, for a person who is placed under custody because he is mentally handicapped (crazy) so that he cannot be questioned about himself, then it is not necessary to summon the candidate for Curandus, only based on information from the family or by marriage. If the qualified candidate is unable to transfer himself, then the examination must be carried out at his residence, by one or several judges appointed for that purpose, accompanied by a clerk, and above all also attended by the prosecutor's office (Article 439 of the Civil Code).

- If the court has obtained sufficient information, the court may render a decision on the request letter without further procedure. On the other hand, if the information is deemed insufficient, the District Court must order the examination of witnesses so that the events presented are clear (Article 440 of the Civil Code).

- After conducting an examination, if due to certain reasons, the District Court may appoint a temporary administrator to take care of the personal and property of the person for whom pardon is requested. After the court has made a decision and the decision has permanent legal force, a supervisor is appointed and the temporary management task ends. (Article 441 of the Civil Code).

- The decision on a request for pardon must be made in an open session, after hearing or legally summoning all parties and based on the conclusion of the Prosecutor (Article 442 of the Civil Code).

- All stipulations and decisions of the Judge ordering a pardon, within the time stipulated in this stipulation or decision must be notified by the party requesting pardon to the opposing party and announced by placing it in the State Gazette (Article 444 of the Civil Code).

With the stipulation of forgiveness, people who are adults are placed in a situation where they must be helped by others, or depend on others, and their position is in many respects the same as those of those who are not old enough. 
Because basically a person who is placed under guardianship does not have the ability to act alone in carrying out legal actions or actions so that he must be represented by the guardian.

\subsection{The Process After the Deed of Sharing Joint Rights Is Made by PPAT}

After the requirements are fulfilled and the APHB has been drawn up and read out, the PPAT is in charge of registering the transfer of land rights to the local Land Office. The distribution of joint rights to land or property rights becomes the right of one of the joint rights holders based on the APHB made by the authorized PPAT according to the applicable regulations which can prove the agreement between the joint rights holders regarding the distribution of the joint rights must be registered.

APHB is a deed made by PPAT to prove that there has been an agreement between joint rights holders regarding the distribution of joint rights to land which can be used as the basis for land registration. One of the objectives of land registration is to provide legal certainty and legal protection to holders of rights to a parcel of land, apartment units, and other registered rights so that they can easily prove themselves as holders of the rights in question.

\subsection{Form of Deed of Shared Rights}

The form of the PPAT deed is regulated in the Regulation of the Head of the National Land Agency Number 8 of 2012 concerning Amendments to the Regulation of the Minister of State for Agrarian Affairs/Head of BPN RI Number 3 of 1997 concerning Land Registration or known and called PERKABAN 8/2012. The PPAT deed not only serves as evidence, but also functions as a registration requirement for changes to land registration data. Perkaban 8/2012 only stipulates 1 (one) copy of the second PPAT Deed which is submitted to the local Land Office for registration purposes, and specifically Article 4 paragraph 2 of the Regulation of the Head of BPN Number 1/2006 also allows more than 1 (one) copy to be made second, for the deed of exchange,

Only the PPAT deed made in accordance with the form and procedure for filling out as regulated in PERKABAN 8/2012 can be used as the basis for registering changes to land registration data. The local Land Office will refuse the registration if the PPAT deed is made not in accordance with the form and filling procedure as stipulated in PERKABAN 8/2012. The form of the PPAT deed as 
regulated in PERKABAN 8/2012 includes the Deed Cover and Deed Form (head of deed, beginning of deed, comparison, contents of deed and end of deed). ${ }^{11}$

\section{Closing}

Based on the research and discussion conducted, the following conclusions can be drawn: 1) PPAT has an important role because PPAT is a General Official who has the task of assisting the parties to achieve their desire to share joint rights of a land right and convey all requirements before registering the transfer of rights on the basis of APHB at the Land Office. In addition, the PPAT has the authority to make APHB. 2) Incompetent heirs due to mental disabilities, the heirs are represented by a guardian. An heir with a mental disability cannot carry out a legal act in any form that can result in legal consequences, but an heir with a mental disability still has the right to inherit, but to use the inheritance he must be placed under guardianship. Forgiveness can be requested at the District Court and a guardian must be responsible for errors or omissions in carrying out the obligations of managing and/or settling the affairs of the competent person. 3) After the APHB is made and read out, the PPAT is obliged to register the transfer of land rights to the local Land Office. 4) The form of the APHB made by PPAT, in order to be able to register at the Land Office, it is required to follow the provisions of the Regulation of the Head of the National Land Agency Number 8 of 2012 concerning Amendments to the Regulation of the State Minister of Agrarian Affairs/Head of BPN RI Number 3 of 1997. The form of the PPAT deed which is regulated includes Cover Deed and Deed Form (head of deed, beginning of deed, comparison, contents of deed and end of deed).

\section{References}

Journals:

[1] Deen, Thaufiq., Ong Argo Victoria \& Sumain. (2018). Public Notary Services In Malaysia. JURNAL AKTA: Vol. 5, No. 4, 1017-1026. Retrieved from http://jurnal.unissula.ac.id/index.php/akta/article/view/4135

[2] Tatik Arjiati, Peran Notaris/PPAT dalam Pembuatan Akta Pembagian Hak Bersama (APHB) terhadap Pembagian Waris yang Berbeda Agama atas Tanah dan Bangunan, Jurnal Akta Vol. 4. No. 1,(Semarang: Universitas Islam Sultan Agung, 2017).

Books:

[1] Laura Chrismetin, Peran Pejabat Pembuat Akta Tanah (PPAT) Dalam Pembuatan Akta Pembagian Hak Bersama (APHB) Terhadap Pembagian

\footnotetext{
11 https://medianotaris.com/teknik_pembuatan_akta_ppat_versi_perkaban_berita338.html accessed on Monday, July 26 2021, 23:10 WIB.
} 
Waris Dalam Hukum Islam Atas Tanah Dan Bangunan Di Kabupaten Brebes, (Tegal: Universitas Pancasakti, 2019);

[2] Yosvita Prasetyaningtyas, Hukum untuk Orang Awam, (Yogyakarta: Efata Publising, 2014).

\section{Regulations}

[1] Act No. 1 of 1974 concerning Marriage;

[2] Act No. 3 of 2006 concerning Amendments to Act No. 7 of 1989 concerning Religious Courts;

[3] Act No. 5 of 1960 concerning Basic Regulations on Agrarian Principles;

[4] Circular Letter of the Supreme Court Number 3 of 1963 concerning the idea of not considering Burgerlijk Wetboek as a law;

[5] Code of Civil law

[6] Constitution of 1945 the Republic of Indonesia;

[7] Government Regulation Number 37 of 1998 concerning Regulation of the Position of Land Deed Maker Officials;

[8] Government Regulation of the Republic of Indonesia Number 24 of 1997 concerning Land Registration;

[9] Regulation of the Head of the National Land Agency Number 1 of 2006 concerning Provisions for the Implementation of PP Number 37 of 1998 concerning the Regulation of the Position of the Official for Making Land Deeds;

[10] Regulation of the Head of the National Land Agency Number 8 of 2012 concerning Amendments to Regulation of the Minister of State for Agrarian Affairs/Head of BPN RI Number 3 of 1997 concerning Provisions for the Implementation of Government Regulation Number 24 of 1997 concerning Land Registration;

[11] Regulation of the State Minister of Agrarian Affairs/Head of the National Land Agency Number 3 of 1997 concerning Provisions for the Implementation of Government Regulation Number 24 of 1997 concerning Land Registration.

Internet:

[1] https://hellosehat.com/mental/mental-lainnya/keterbelakanganmental/;

[2] https://medianotaris.com/teknik_pembuatan_akta_ppat_versi_perkaban _berita33.html;

[3] https://ngobrolinhukum.wordpress.com/2014/08/09/data-sekunderdalam-penelitian-hukum-normatif/;

[4] https://www.kennywiston.com/sekilas-tentang-hukum-pengampuan/ 